\title{
GOOD FAITH PERFORMANCE AND COMMERCIAL REASONABLENESS UNDER THE UNIFORM COMMERCIAL CODE*
}

\section{E. Allan Farnsworthi}

$\mathrm{P}$ ROFESSOR GUTTERIDGE, writing of the codes of civil law countries, has elegantly described their important general concepts as "overriding and super-eminent principles." 1 This is a propitious moment to revisit two of the general concepts of the Uniform Commercial Code-those of good faith and commercial reasonableness. For roughly a decade we were treated to the discussions that attended the drafting of the Code. For roughly a decade we have been subjected to debate on its merits. The Code is now well on its way to adoption throughout the United States. But it remains to be seen whether it will succeed as a coherent and integrated codification rather than just a collection of related articles-whether the whole of the Code is anything more than the sum of its parts-whether the Code has any truly "overriding and super-eminent principles."

Let me first outline the Code's provisions on this topic. Because the numerology of the Code has been known to produce a syndrome among lawyers like that caused by all-digit dialing among telephone subscribers, I shall refer to the Code sections by description in preference to number. The key section is the general obligation of good faith ${ }^{2}$ contained in Article 1, the Code's General Provisions. It declares that, "every contract or duty within this Act imposes an obligation of good faith in its performance or enforcement." The comment states that "This section sets forth a basic principle running throughout this Act." The general definition of good faith, also contained in Article 1,3 defines "good faith" to mean "honesty in fact in the conduct or transaction concerned." Article 2, the Sales article, however, contains a special merchant's definition of "good faith" under which "good faith" in that article means "honesty in fact and the observance of reasonable com-

* This article is based on an address delivered at the conference on the Uniform Commercial Code held at the University of Chicago Law School on November 1,1962. I wish to express my appreciation to Professor Soia Mentschikoff and Professor William E. Hogan for their suggestions during revision of the manuscript for publication.

$\dagger$ Professor of Law, Columbia University School of Law.

1 Guttertoge, Comparative Law-An Introduction to the Comparative Method of LEGAL STUDY AND RESEARCH 94 (2d ed. 1949).

2 UNIFORM COMMERCLAL CODE § 1-203 [hereinafter cited as UCC when referring to the 1958 Official Draft].

3 UCC \$1-201(19). 
mercial standards of fair dealing in the trade."4 All in all, there is express mention of "good faith" in some fifty out of the four hundred sections of the Code. "Commercial reasonableness," in contrast, is neither embodied in a a general provision nor defined, but it figures prominently in somewhat variant language throughout the Code, 5 often in connection with "good faith." The most significant juxtaposition of the two terms appears in the merchant's definition of good faith just quoted.

\section{The Two Senses of "Good FaIth"}

The Code uses the term "good faith" in two fundamentally different senses. This is hardly surprising. "Good faith" has long been the darling of draftsmen. Field used it in his Civil Code; 6 Chalmers in the British Bills of Exchange and Sale of Goods Acts; Crawford in the Negotiable Instruments Law and Williston in the Uniform Sales Act. At least four contemporary federal statutes bear witness to its versatility: Under the Labor-Management Relations Act of 1947, employer and union are bound to "confer in good faith"; 7 under the Robinson-Patman Act a seller may discriminate if his price was set "in good faith" to meet competition;8 under the Bankruptcy Act a petition for a Chapter X reorganization must be filed "in good faith"; 9 and under the Automobile Dealer Day in Court Act the dealer may recover damages sustained because of the manufacturer's failure to act "in good faith."10 Indeed, for over a decade it has been the custom for each member of the outgoing class at The University of Chicago Law School to take Karl Llewellyn's pledge that he will "work always with care and with a whole heart and

4 UCC § 2-103(1)(b).

5 Compare, e.g., UCC $\$ 2-306(1)$ (output or requirements term means "such actual output or requirements as may occur in good faith, except that no quantity unreasonably disproportionate" to stated estimate or normal prior experience may be tendered or demanded), with \$2-311(1) (specification of particular of performance by one of the parties "must be made in good faith and within limits set by commercial reasonableness"). (Emphasis added.)

6 "The offer of performance must be made in good faith by the party owing performance to the party who is entitled to the same, and the former must be ready and willing to perform his obligation . . . ." FIELD's CIVIL CODE $\$ 642$ (New York State Commissioners' Draft of a Civil Code for the State of New York (1862). Cf. Cal. Crv. CoDE § 1493 (1941): "An offer of performance must be made in good faith, and in such manner as is most likely, under the circumstances, to benefit the creditor."

7 § 8(d), 61 Stat. 142 (1947), 29 U.S.C. § 158(d) (1958).

8 \$2(b), 49 Stat. 1526 (1936), 15 U.S.C. $\$ 13(b)$ (1958).

9 § 141, 52 Stat. 887 (1938), 11 U.S.C. \$ 541 (1958); see also § 146, 52 Stat. 887 (1938), 11 U.S.C. $\$ 546$ (1958).

$10 \$ 2,70$ Stat. 1125 (1950), 15 U.S.C. $\$ 1222$ (1958). The term is defined in $\$ 1(\mathrm{e}), 70$ Stat. 1125 (1956), 15 U.S.C. $\$ 1221$ (e) (1958). "The term 'good faith' shall mean the duty of each party to any franchise, and all officers, employees, or agents thereof to act in a fair and equitable manner toward each other so as to guarantee the one party freedom from coercion. intimidation, or threats of coercion or intimidation from the other party." 
with good faith."11 While the varieties of good faith are not quite as infinite as those of religious faith, it would be quite extraordinary if this protean concept were used in the same sense in all of these assorted instances. We may count ourselves fortunate that we need speak of good faith in but two senses.

One group of Code sections, involves what may be loosely described as "good faith purchase."12 Here "good faith" is used to describe a state of mind: A party is advantaged only if he acted with innocent ignorance or lack of suspicion. This meaning of "good faith" is very close to that of lack of notice. Two classic illustrations come to mind. Whether the holder of a negotiable instrument is a holder in due course depends, under the Code, on whether he purchased in good faith.13 Whether the purchaser of goods takes good title from a seller whose own title is voidable because of fraud depends, under the Code, on whether he purchased in good faith.14 In addition, the Code also uses "good faith"- as did prior law-in substantially the same sense in protecting others than purchasers, and these situations will be included in this discussion under the generic term "good faith purchase." Whether a warehouseman or carrier who receives stolen goods and redelivers them to the thief is protected as against the true owner depends, under the Code, upon whether he received and delivered them in good faith. 15 Whether a drawee bank that pays a holder on an altered check may recover the payment depends, under the Code, upon whether the drawee paid in good faith. 16

In a second and smaller group of Code provisions, "good faith" is used to describe performance or enforcement rather than purchase. In this sense, "good faith" has nothing to do with a state of mind-with innocence, suspicion, or notice. Here the inquiry goes to decency, fairness or reasonableness in performance or enforcement. This sense of the term may be characterized as "good faith performance" to distinguish it from "good faith purchase" and is the sense in which "good faith" is used in the general obligation of good faith. ${ }^{17} \mathrm{It}$ is also the sense in which that term is used in a number of more specific sections. If the parties to a sales contract leave price or performance terms open, to be fixed by either buyer or seller, that party is to fix them, under the Code, in good faith. 18 If they describe the quantity as seller's output or buyer's requirements, their obligations are defined under the Code in terms of such output or requirements as may occur in good faith.19 If a mer-

11 See the Chicago Lawyer's Pledge, Llewellyn, JuRisprudence-Realism IN TheOrY AND PRACTICE 395 (1962).

12 On good faith purchase generally, see Gilmore, The Commercial Doctrine of Good Faith Purchase, 63 YALE L.J. 1057 (1954).

13 UCC $\S \S 3-205,3-302$.

$14 \mathrm{UCC} \S 2-403(1)$.

17 UCC \$ 1-203.

15 UCC \$ 7-404.

18 UCC $\$ \$ 2-305$ (2), 2-311(1).

16 UCC $\$ 3-417(1)(c)$.

19 UCC § 2-306(1). 
chant buyer is left in possession of goods that he has rightfully rejected, his obligation to effect salvage under the Code is one of good faith. ${ }^{20}$ Or if the seller, before performance, has assigned his right to payment under his contract with the buyer, their power to modify their agreement, even after notice, is limited by the requirement that the modifications must be made in good faith.21 In each of these instances "good faith" would appear to be used in the sense of good faith performance. And each represents a specific application of the general obligation of good faith-resulting in an implied term of the contract requiring cooperation on the part of one party to the contract so that another party will not be deprived of his reasonable expectations.

The inclusion of an obligation of good faith performance in the Code revives an ancient, although largely forgotten, principle. Consider, for a moment, the origin of the term "good faith." That venerable shibboleth has a faintly pious ring to it. Judge Hough saw in the use of "faith" a "recognition of the obligations of morals and honor."22 "Faith," "morals," "honor"curious terms for the law to employ in describing the behavior of commercial men. Others are available. We might speak of "honesty," as does the Code's general definition of good faith. We might speak of "reasonableness" or of "fairness," as does the Code's merchant's definition of good faith. Or we might speak of "innocence" or lack of "suspicion," as do the Restatements of Contracts and Restitution. ${ }^{23}$ But we do not. None of these has had the universal appeal of "good faith."

While this article is not a discussion of how the Uniform Commercial Code would change Roman Law, it is instructive to consider briefly the origins of this less familiar of the Code's two senses of good faith. Roman law used the informal consensual contract, for a limited but commercially important group of transactions, including the sale. As Professor Lawson has so neatly described it, in actions on the consensual contracts the defendant, if unsuccessful, was directed to pay the plaintiff whatever the judge

"[F]ound to be due ex bona fides, that is to say, in accordance with the requirements of good faith; and this cast on the judge, or rather the jurists who advised him, the burden of deciding what the defendant ought in good faith to have done, in other words what kind of performance the contract called for. This meant that, in contrast to the stipulation, where all the terms had to be expressed, the parties would be bound not only by the terms they had actually agreed to, but by all the terms that were naturally implied in their agreement."24

20 UCC $\$ 2-603(3)$.

21 UCC $\$ 9-318(2)$.

22 Gerseta Corp. v. Wessex-Campbell Silk Co., 3 F.2d 236, 238 (2d Cir. 1924).

${ }^{23}$ See REstateMENT, CONTRACts $\$ 504$ (1932) (reformation for mutual mistake available "if innocent third parties will not be unfairly affected thereby"); RESTATEMENT, RESTrTuTrON $\$ 10$ (1937) (distinction between "doubt and suspicion").

24 Lawson, A Common LaWyer LoOks at the Crvil LaW 124-25 (1955). 
Note that as to these commercially important contracts, "good faith" was used in classical Roman law in the same sense in which it is used in the Code's general obligation of good faith-in the sense of good faith performance; and its significance was in implying terms in the agreement, just as it is under the Code. It was not until a later period of Roman law that "good faith" came to be used in the sense of good faith purchase.

Concern with "good faith" in relations among commercial men found its way into the English law merchant-both in connection with purchase and performance. In Holdsworth's view it was the canon law that "put into legal form the religious and moral ideas which, at this period, colored the economic thought of all the nations of Europe," and thus "contributed to enforce those high standards of good faith and fair dealing which are the very life of the trade."'25 But by the eighteenth century, when the law merchant had been absorbed into the common law, the attention of the King's courts began to be concentrated upon the development of a body of doctrine to encourage the free circulation of goods and commercial paper. Good faith purchase-not good faith performance-was the concern of the day, and the courts set about the task of defining "good faith" for this purpose. The leading cases involved the test of "good faith" for a holder in due course of a negotiable instrument. In 1801, in Lawson v. Weston, ${ }^{26}$ Lord Kenyon ruled that the holder need not make diligent inquiry when he takes the instrument, and-with the grim prediction that to require such an inquiry "would be at once to paralise the circulation of all the paper in the country"-he introduced the subjective test of actual good faith, the test of "the pure heart and the empty head." In 1824, in Gill v. Cubitt, 27 the subjective test was discarded for an objective test that required the holder to exercise the prudence and caution of a reasonable man. Chief Justice Abbott, not above engaging in a bit of sociological jurisprudence himself, darkly suggested that the rule in Lawson $v$. Weston has been responsible for a very considerable practice of robbing stagecoaches of negotiable securities. But by 1836 Gill v. Cubit thad been overruled in England 28 and by the end of the nineteenth century most of the American states had adopted a subjective test for good faith purchase. 29

This attention to good faith purchase, to the exclusion of good faith performance, seems to have led to two general misconceptions: First, that good faith referred only to purchase; and second, that the proper test of good faith was always subjective. The uniform acts that preceded the Code contain up-

255 Holdsworth, A History of ENGlish LaW 79-81 (2d ed. 1937).

264 Esp. 56, 170 Eng. Rep. 640 (K.B. 1801).

273 B. \& C. 466, 107 Eng. Rep. 806 (K.B. 1824).

28 Goodman v. Harvey, 4 A. \& E. 870, 111 Eng. Rep. 1011 (K.B. 1836).

${ }^{29}$ In Goodman v. Simonds, 61 U.S. (20 How.) 343 (1857), the Supreme Court of the United States determined to follow Goodman v. Harvey, repudiating Gill v. Cubitt. Id. at $367-70$. 
wards of fifty references to good faith, and not once is that term used in the sense of good faith performance. A subjective test of "honesty in fact" is used consistently throughout the uniform acts.

Professor Raphael Powell has maintained that there is in English law today "no overriding general positive duty of good faith imposed on the parties to a contract." 30 In this country, the courts of a few states, notably those of New York and California, did continue to assert that every contract includes an implied obligation of good faith and fair dealing. The situations in which they did so were usually those in which one party's compensation was fixed in terms of a percentage of the other's profits, receipts, sales or production and the obligation of good faith was the basis of implying a condition of cooperation by the party who was to pay. ${ }^{31}$ But by the time of the promulgation of the Uniform Commercial Code, good faith performance had, in spite of its ancient lineage, become a poor and neglected relation of good faith purchase. The Code revives it and uses good faith in both senses-good faith purchase and good faith performance.

\section{The Proper Standard of Good Faith Performance}

Good faith performance properly requires some objective standard tied to commercial reasonableness. As to good faith purchase, the case can be made for either the subjective test of Lawson $v$. Weston, or the objective test of Gill $v$. Cubitt. The inquiry goes to a state of mind. There is, at least on the face of it, nothing inherently implausible in a subjective standard looking to actual ignorance or lack of suspicion, and nothing inherently implausible in an objective standard looking to the ignorance or lack of suspicion to be expected of a reasonable man under the same circumstances. Authority happens to favor the subjective test in order to promote the circulation of goods and commercial paper.

But is there a choice between two plausible standards for good faith performance? Clearly good faith performance can be measured by an objective standard based on the decency, fairness or reasonableness of the community, commercial or otherwise, of which one is a member. Is a subjective standard of good faith an appropriate alternative? Is a subjective standard sufficient to

30 Powell, Good Faith in Contracts, 9 Current Legal Prob. 16, 25 (1956).

31 In an illustrative New York case, a producer of cattle food agreed to install, at considerable expense, a machine for drying and salvaging wet grains that were the by-product of a brewery. In exchange it received the brewery's promise to sell it the used grain that it produced and salvaged for a period of five years or until half a million barrels had been brewed, after which the brewery was to become the owner of the machine. The brewery sold out its business before either of these events occurred. The New York Court of Appeals held it liable to the producer of cattle food for damages. A promise to remain in business for five years or until half a million barrels had been brewed was implied. "Every contract," said the court, "implies good faith and fair dealing between the parties to it." Wigand v. BachmannBechtel Brewing Co., 222 N.Y. 272, 277, 118 N.E. 618, 619 (1918). See also Universal Sales Corp. v. California Press Mfg. Co., 20 Cal. 2d 751, 128 P.2d 665 (1942). 
test good faith in fixing an open contract term, in determining output or requirements, in effecting salvage of rejected goods or in modifying a contract after assignment? In each of these instances the Code has explicitly incorporated an objective standard. 32 Would a test based on the individual's actual state of mind with no appeal to common practices make any sense in these cases? Surely the test is not whether one party actually, believed that he was acting decently, fairly or reasonably. Surely he must do more than form an honest judgment. Otherwise no more than knowing and deliberate unfairness, maliciousness, trickery and deceit would be forbidden.

It is true that the gap between the objective and subjective tests may in practice be less than has just been suggested. Under a subjective test of good faith it is always open to the trier of the facts to evaluate the credibility of a claim of "honesty in fact," and in doing so to take account of the reasonableness or unreasonableness of the claim. But even if it were assumed that the subjective test, as applied, would in most cases yield the same result as the objective test, there is scant justification in leaving to the complexities of the process of proof the task of accomplishing an end that could be attained by a straightforward and appropriate rule of substantive law. 33

Furthermore, the chief utility of the concept of good faith performance has always been as a rationale in a process which is not intrusted to the trier of the facts-that of implying contract terms. It was so even under Roman law; it was so under the pre-Code case law in this country; and it remains so under the Code. Good faith performance has always required the cooperation of one party where it was necessary in order that the other might secure the expected benefits of the contract. And the standard for determining what cooperation was required has always been an objective standard, based on the decency, fairness or reasonableness of the community and not on the individual's own beliefs as to what might be decent, fair or reasonable. Both common sense and tradition dictate an objective standard for good faith performance.

32 The standard is explicit in UCC $\$ \S 2-306(1), 2-311(1)$ and 9-318(2). The merchant's standard of good faith, set out in $\$ 2-103(1)(b)$, is incorporated in UCC $\$ \$ 2-305(2)$ and $2-603(3)$, as well as in the three sections cited above, because of the express requirement of "good faith."

${ }^{33}$ At this point a few words as to UCC $\$ 1-208$ are in order. That section provides that a provision for acceleration of payment or performance "at will" shall be construed to give the accelerating party the power to do so only "if he in good faith believes that the prospect of payment or performance is impaired." Since this section is in Article 1, the standard of good faith is subjective, even in the case of a merchant, and this is emphasized by the use of the word "believes." This is in itself noteworthy because acceleration is a matter of good faith performance, rather than good faith purchase for which the Code expressly lays down a subjective standard. The section also puts the burden of proving lack of good faith on the party against whom the power has been exercised. Nevertheless, if the Code makes any change in this regard, it probably favors the person against whom the power has been exercised. 


\section{The Code's Standard of Good Faith Performance}

The Code's provisions on good faith do not consistently use an objective test for good faith performance. To understand why they do not it is useful to go back to the 1950 draft of the Code. 34 The general obligation of good faith was in substantially the same language in the $1950 \mathrm{draft}$ as it is today. The Code did not at that time, however, have a special merchant's definition of good faith. Instead, it defined good faith for all purposes in its general definition of good faith in Article 1, and this single, unitary definition was applicable throughout the Code. That definition was significantly different from the present one, for "good faith" was defined not only to mean "honesty in fact," as it does today, but also to include observance "of the reasonable commercial standards of any business or trade in which he is engaged." It therefore added an objective standard to both good faith performance and good faith purchase. But by 1952, when the Code was first put up for adoption, the "reasonable commercial standards" clause had been removed from the general definition of good faith. This was done at the suggestion of the American Bar Association's Section of Corporation, Banking and Business Law, which-suffering from the misconceptions mentioned earlier-thought that to the average person and the average lawyer "good faith" meant only honesty. ${ }^{35}$ After the removal of this language from the general definitions section of Article 1, similar language was inserted in the merchant's definition of "good faith" in Article 2 (Sales), in the holder in due course section in Article 336 (Commercial Paper), and in a few other sections. The demise of the single, unitary definition of good faith had one very important resultthe definition of good faith performance in the key general obligation of good faith was shorn of any reference to reasonable commercial standards and limited instead to honesty in fact. This, it seems, was one of the major casualties during the drafting of the Code. The American Bar Association section recognized this and suggested that if the definition of good faith were limited to honesty in fact, the general obligation of good faith could be eliminated as

34 Looking to the 1950 draft does raise an embarrassing problem: The 1952 text of the Code would have put all prior drafts out of bounds with a provision that "prior drafts of text and comments may not be [used] to ascertain legislative intent." UCC \$1-102(3)(g)(1952). When the Code was revised this provision was deleted at the suggestion of the New York Law Revision Commission. But the reason given by the editorial board was that "the changes from the text enacted in Pennsylvania in 1953 are clearly legitimate legislative history." Reason for Recommendations to Uniform Commercial Code 1-102, 1956 RECOMMENDATIONS OF THE EDITORIAL BOARD FOR THE UNIFORM COMMERCIAL CODE 3 (1957). See Braucher, The Legislative History of the Uniform Commercial Code, 58 CoLUM. L. REv. 798, 809 (1958). This suggests that it is still not proper to go back beyond 1952. Perhaps there are valid reasons for not disturbing the skeletons in the editorial board's closet. Still, we may learn from examining a few old bones.

${ }^{35}$ American Bar Association Report of Committee on the Proposed Commercial Code, 6 Bus. LAw. 119, 128 (1951).

36 UCC $\$ 3-302(1)(b)$. 
unnecessary.37 Although not eliminated, it was so enfeebled that it could scarcely qualify at this point as an "overriding" or "super-eminent" principle.

But good faith purchase rather than good faith performance continued to hold the spotlight. The emasculation of the general obligation of good faith occasioned far less controversy than did the insertion of some of the discarded language in Article 3 on Commercial Paper. For the requirement of "reasonable commercial standards," exorcised from the general obligation of good faith, came to rest in the requirement of good faith for holding in due course. Here it came under vigorous attack by those who saw in it a return to the objective test of Gill $v$. Cubitt. The critics again prevailed, and the language was dropped from the holder in due course section. ${ }^{38}$ But this had no effect upon the already enfeebled obligation of good faith performance. 39

These remarks are not intended as criticism of the draftsmen of the Code for compromise and accommodation that was inevitable in an enterprise of such magnitude and duration and in which so many conflicting voices were to be heard. But the end result was that the requirement of observance of reasonable commercial standards that had given a unity to the general obligation of good faith performance as it applied to all articles of the Code under the 1950 draft was carved up and dispersed among a relatively small number of sections. Like Humpty Dumpty, the general obligation of good faith had had a great fall.

\section{The Future of Good Faith Performance Under the Code}

The future vitality of the Code's obligation of good faith performance will depend largely upon the post-operative care that it receives at the hands of the courts. Whether all the King's horses and all the King's men can put the obligation together again is a matter for the judiciary. A number of important questions of interpretation of the Code must be resolved. This article will raise but a few of them.

37 American Bar Association Report of Committee on the Proposed Commercial Code, supra note 35.

38 Insofar as good faith purchase is concerned, where the Code requires lack of notice as well as good faith, the purchaser will be faced with the objective standard of UCC $\$ 1-201(25)$, which provides that, "A person has 'notice' of a fact when ... from all the facts and circumstances known to him at the time in question he has reason to know that it exists."

39 It does, however, explain why the standards for good faith purchase differ, for example, as between the bank that purchases commercial paper and is held only to a purely subjective standard of good faith in order to become a holder in due course under UCC 3-302(1)(b), and a merchant who purchases goods and must also observe "reasonable commercial standards of fair dealing in the trade" in order to become a good faith purchaser under UCC \$2-403(1). However, the bank must also take without notice in order be a holder in due course, and must, therefore, meet the test set out in note 38, supra. Since this discussion is directed primarily at good faith performance rather than at good faith purchase, no attempt has been made to explore the Code's other variants on the latter. See, e.g., UCC \$1-201(9) ("buyer in ordinary course of business" defined). 
One concerns the extent to which an objective standard of good faith is to be applied in Article 2, the Sales article. In a few sections of that article the objective standard is specific, as in the provision on open terms of performance, which are to be specified by one of the parties "in good faith and within limits set by commercial reasonableness." 40 In other sections of that article, such as the provision on open price terms, 41 there is no specific objective standard, but the term "good faith" is expressly mentioned so that the merchant's definition with its objective standard clearly applies where a merchant is involved. But what of the great majority of sections in the Sales article as to which there is only a general obligation of good faith based on the provisions of Article 1? Is the merchant's definition of good faith to be read into the general obligation of good faith in a sales contract made by a merchant when the controversy arises under one of these sections? The comment to the section defining the general obligation of good faith suggests an affirmative answer: "[U]nder the Sales Article definition of good faith . . . contracts made by a merchant have incorporated in them the explicit standard not only of honesty in fact . . . but also of observance by the merchant of reasonable commercial standards of fair dealing in the trade." 42 If this is so, the general obligation of good faith would at least in sales contracts made by merchants have substantially the effect intended in the 1950 draft. Unfortunately, the text of the Code does not clearly support the comment. The merchant's definition of good faith says only that, "In this Article unless the context otherwise requires ... 'Good Faith' in the case of a merchant' includes observance of such standards. On a literal reading, this definition would apply only when the term "good faith" is used "in this Article"-the Sales article. It would not then apply where the obligation of good faith had to be imported from the general obligation of good faith in Article 1, even if the contract to which that obligation applied happened to be a sales contract and even if the controversy happened to arise under an Article 2 (Sales) section.

Take as an illustration the Code's provisions on modification of a sales contract ${ }^{43}$ which provide that "an agreement modifying a contract within this Article [Article 2] needs no consideration to be binding." There is no express requirement of good faith in the text of that section. Suppose that a merchant seller in a rising market refuses to perform for no other reason than to extort a higher price from the buyer who desperately needs goods that are in short supply. Such a modification of price would be ineffective because, as the comment points out, the seller "must meet the test of good faith imposed by this Act," 44 and he has presumably not met even the subjective test of "honesty in fact." Suppose, however, that the seller has a colorable claim for an in-

40 UCC $\$ 2-311(1)$.

41 UCC $\$ 2-305(2)$.

$43 \mathrm{UCC} \$ 2-209$.

42 UCC $\$ 1-203$, comment.

44 UCC \$2-209, comment 2. 
crease in price based on his own increased costs, so that he can meet the subjective test of good faith. Is the merchant's definition of good faith in Article 2 to be read into his general obligation of good faith in Article 1 as it applies to the modification section in Article 2 so that he must have observed "reasonable commercial standards of fair dealing in the trade"? The comment to the modification section states flatly that the merchant's definition applies, but the text of the Code appears to give uncomfortably little support to this salutary result. It will be up to the courts to make sure that the text is "liberally construed," as the Code expressly requires, 45 if the merchant's defininition of good faith is to be read into the general obligation of good faith in sales contracts.

Suppose that it is read in. The court must then determine what is meant by "reasonable commercial standards of fair dealing." How does fairness, which suggests decency, differ from reasonableness? In a few sections standard is piled upon standard. Take the merchant seller who is to specify particulars of performance that have been left open in a sales contract. 46 Under the general obligation of good faith, he must meet the test of "honesty in fact." This is one standard. Because he is a merchant, he must observe "reasonable commercial standards of fair dealing in the trade." This is a second standard. And because the applicable section specifically requires it, he must act "in good faith and within limits set by commercial reasonableness." And this is a third standard. And how do the three-especially the second and third-differ? Or take the merchant buyer who rejects goods claiming minor defects in quality when in fact he is motivated solely by a sharp drop in the market. Is it conceivable that he has violated his general obligation of good faith in the sense of "honesty in fact"? Is it possible that he has violated his obligation to observe "reasonable commercial standards of fair dealing in the trade" ?47

It was not to be expected that the Code would supply ready-made answers to these questions. Part of the strength of such general concepts as "good faith" and "commercial reasonableness" lies in an elasticity and lack of precision that permits them to be, in the language of the Code's own comments, "developed by the courts in the light of unforeseen and new circumstances and practices." 48 If a viable obligation of good faith performance is to be born out of the Code's provisions, it will require skilled judicial midwifery in matters of application.

This leads to the related question of how much use the courts can make of commercial practices in applying the requirements of good faith. The comment to the general obligation of good faith makes the claim that, "It is further

45 UCC $\$ 1-102(1)$.

46 UCC § 2-311(1).

47 This possibility is suggested in Honnold, Buyer's Right of Rejection, 97 U. PA. L. REV. 457,475 (1949).

48 UCC \$1-102, comment 1. 
implemented by Section 1-205 on course of dealing and usage of the trade."49 Where the general obligation of good faith requires only "honesty in fact" it is difficult to see how it could be meaningfully "implemented" by course of dealing or usage of trade (except as they may go to the credibility of claims of honesty). Only to the extent that the test is objective do commercial practices become vital in establishing the standards of good faith. If the courts should refuse to read the merchant's definition of good faith into the general obligation of good faith performance in sales contracts, the effective role of commercial practice in determining good faith performance would be limited to the small number of sections in which a standard of reasonableness is expressly included or in which the term "good faith" is expressly mentioned. To be sure, the section on course of dealing and usage of the trade provides for reading commercial practices into the contract 50 and this may be an alternate ground to that of good faith for implying terms. However, the merchant's definition of good faith requires only a showing of "reasonable commercial standards of fair dealing," which is presumably something less than proof of a course of dealing or usage of the trade.51

Assuming, however, that a court will read in an objective standard where possible and accord a generous role to commercial practices in determining that standard, what opportunity have the parties to modify the resulting rules by express agreement? The Code section on variation by agreement suggests that they have very little. It provides that "the obligations of good faith, diligence, reasonableness and care" prescribed by the Code "may not be disclaimed by agreement but the parties may by agreement determine the standards by which the performance of such obligations is to be measured if such standards are not manifestly unreasonable." 52 What will be the effect of this section upon contract provisions that attempt to vary terms relating to cooperation? If the term is implied under the general obligation of good faith and if the general obligation of good faith cannot be disclaimed by agreement, does it follow that the implied term cannot be modified by agreement?

It seems clear that this should not always be the case. For example, one of the sections of Article 253 requires the buyer, under certain circumstances, to afford the seller an opportunity to cure a defective tender of goods by making

49 UCC \& 1-203, comment.

50 UCC § 1-205(3).

51 The imposition of "reasonable commercial standards of fair dealing" is, however, something different from the imposition of a general standard of due care. See 1956 RECOMMENDATIONS OF THE EDITORIAL BOARD FOR THE UNIFORM COMMERCIAL CODE 21.

52 UCC $\$ 1-102(3)$. It is at least arguable that this would permit a merchant seller and a merchant buyer, without disclaiming their obligations of good faith, to provide that the standard by which they are to be measured should be only the subjective standard of "honesty in fact" and not the merchant's standard.

s3 UCC \& 2-508. 
a conforming tender. It is pointed out in the comment to the general obligation of good faith that this is a particular application of the general obligation. Yet the comment to the section on cure states that the requirement that the buyer cooperate in this way can be disclaimed by deliberate inclusion of a "no replacement" clause in the contract. Surely if a statutory provision based on the general obligation of good faith can be varied by agreement, an implied term arising under that obligation can be similarly modified. Nevertheless, if an objective standard is to be read into the general obligation of good faith performance, the limits on variation by agreement of conditions implied under that obligation are far from clear. Since mandatory rules, not subject to agreement by the parties, are not ordinarily favored in our law, it is reasonable to suppose that the obligation of good faith performance and the terms implied under it will be more appealing and more likely of extension if they are more readily subject to modification by agreement than is suggested by the Code section on variation by agreement. It would not be surprising, nor regrettable, if that section were to be restrictively construed in this connection.

\section{v. ConClusion}

The Code uses "good faith" in two senses, that of good faith performance as well as that of good faith purchase; both common sense and tradition favor an objective standard of good faith performance; the Code does not prescribe an objective standard for its general obligation of good faith; but the courts can, by sound construction of the Code, arrive at an objective standard of good faith performance as to sales contracts by a merchant.

This is a modest achievement, extending not to the entire Code and not to all parties, but only to contracts of sale and then only to contracts of sale by merchants. Yet by steps such as this our law grows. And a contract of sale is a very common sort of contract, and a contract of sale by a merchant is a very important kind of contract of sale. Is it not possible that the general obligation of good faith with the merchant's objective standard, may be extended by analogy to contracts not literally within the purview of the Code? The comments to the Code suggest the possibility of such extension. ${ }^{54}$ And it is not without interest that the comparable provision of the German Civil Codes5 is one of the leading examples of an "overriding and super-eminent" principle in a civil law system. That section provides simply that the obligor is bound to perform the contract in good faith (Treu und Glauben), having regard to common usage. Upon the foundation of this principle the German courts have erected an elaborate structure of rules governing, among other matters, the implication of contract terms and the doctrine of frustration. When the German currency collapsed following the First World War and the mark plummeted to less than a billionth of its value at the time of the armistice, it was the

54 UCC $\$ 1-102$, comment 1.

55 Bürgerliches GesetzBuCH $\$ 242$ (Ger. 8th ed. Soergel 1952). 
obligation of good faith that was used as the principal basis of revaluation of debts in terms of the real purchasing power of the mark in spite of specific statutory provision that the mark was legal tender. ${ }^{56}$ Is it not possible that the Uniform Commercial Code's general obligation of good faith with the merchant's objective standard may be extended by analogy to contractssuch as bailments or contracts for services-that are not, strictly speaking, sales contracts, 57 involving professional men of commerce who are not technically merchants? Is it not conceivable that it may serve as a basis for implying conditions other than those of cooperation-for example, as in German law, those that we sometimes call implied conditions of frustration? It may be that if anything is to be learned by a comparison of our own legal system with another, it is only that we learn nothing by comparison. Perhaps it may be too much to expect a common-law system to reason by analogy from the general principles of its statutes. Still, the lesson is there, and the Code's concepts of good faith performance and commercial reasonableness await development, even beyond the bounds of the Code, at the hands of resourceful lawyers and creative judges.

56 The evolution of the German law concerning revaluation is traced in Dawson, Effects of Inflation on Private Contracts: Germany, 1914-1924, 33 Mrch. L. REV. 171 (1934). There is an elementary discussion of this aspect of German law in Powell, Good Faith in Contracts, 9 Current Legal Prob. 16, 29-37 (1956).

57 For an argument that sales warranties should be extended by analogy to bailments and contracts for services, see Farnsworth, Implied Warranties of Quality in Non-Sales Cases, 57 Colum. L. Rev. 653 (1957). 